\title{
Monsanto and Caribbean Agricultural Politics Mark Chatarpal
}

Mark Chatarpal is currently studying at the University of Toronto. With a love for his country Guyana, Mark has maintained strong connections with his home, family and friends. In addition to his studies, Mark does small-scale community based development in Guyana and Roriama, Brazil.

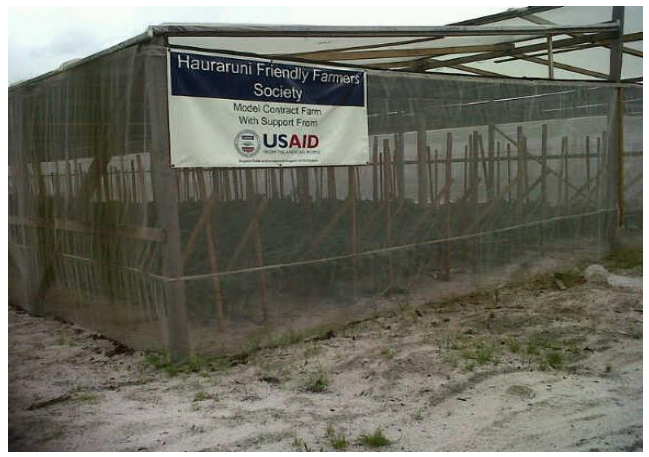

\section{Introduction}

In the past, sovereignty was normally portrayed as the duo between competing states over the possession of land. As land acquisition occurred, states ensured that food production increased. In recent times however the game has changed. Instead of states maintaining sovereignty over food production, multinational companies have monopolized this arena and as a result have acquired great influence over smaller underdeveloped states Large North American based multinational companies (MNCs) continue their onslaught on the global south by underdeveloping the region through the control of the global food supply. The result is that "underdeveloped" states are robbed of the ability to sustain and feed themselves. The greed of the capitalist North actively ensures that peoples of the South become and remain dependant on them for survival. It is in light of this situation that the sovereignty of smaller states and their capacity to produce food independently - away from the influence of the North warrants scrutiny. 
Within this context, my research will focus on food sovereignty beginning with situating the discussion in a regional framework and then broadening the analysis to a global context with a specific case to illustrate the arguments in this paper. In particular, this paper will discuss Monsanto and its links to the Caribbean, focusing on MNC's connection and influence over the agricultural political arena. In short, I aim to outline how Monsanto and Caribbean agricultural politics are inter-related. By inter-related, I mean to highlight, expose and theorize how specifically an American based multinational corporation managed to garner hegemonic influence not only over Latin and South America, but also over the Caribbean and its current inroads into Guyana.

To facilitate this analysis, this report has been divided into seven sections. Firstly, a brief history of Monsanto will be given in order to discuss the connection between Monsanto and Caribbean agricultural politics This section will also attempt to address some initial questions such as: Who are the primary owners of this corporation and how are they interconnected with the interests of the U.S.A? What is the company's involvement in deterring holistic development within smaller countries and also the effects of their business practices? Building upon this foundation, the essay will outline Monsanto's unethical gene patenting practices of various plant species from around the globe, specifically addressing the ways in which Monsanto is actively involved in the process of attempting to establish global ownership of seeds such as rice, corn and soy. Looking at the effect of these detrimental practices $t$, this paper will juxtapose the effect and impact of seed patenting in India, to the company's current expansion of their agro-empire into the Caribbean.

To properly ascertain the susceptibility of the agriculture sector within the Caribbean, highlighting the current state of food security within the region is essential. Why does Monsanto view the Caribbean as 'ripe for the picking'? Through an analysis of a case study of a small village in Guyana, this paper will address the question above by I highlighting the indirect influence of Monsanto within a Caribbean context. The aim here is to stress the negative 
ramifications this MNC along with USAID has on a micro scale. . This section will also include a critique of the government of Guyana's approach to food sovereignty, their official position on Monsanto, and their contradictory practices within the local economy. As an aside, obtaining information these contradictions came at a high price and so this section will also be utilized to briefly discuss the threats that I faced while gathering data for my research.

The final portion of this essay will discuss alternative ways of developing the agriculture sector, away from the claws of MNCs such as Monsanto Following this, the MNCs current involvement in the Caribbean and South America will be addressed in order to explain why Brazil is being regarded by Monsanto as their launch pad for hegemonic agro-domination throughout Latin America and the Caribbean. Importantly, the aim is to address the connection between the U.S government and Monsanto Corp in order to illustrate how this partnership instrumental in suppressing the socialist revolution occurring in Venezuela. The paper will conclude with a discussion of some of the policies that President Hugo Chavez has implemented in a bid to maintain sovereignty and to rid his country of capitalist control.

\section{A Concise History of Monsanto Corp}

“...be mindful of those who say, 'we are here to help you'...”-Arnold Itwaru (A. H. Itwaru)

John F. Queeny initially founded Monsanto Corp in 1901; at that time the company primarily focused on producing artificial sweetener, which was used to bolster sugar-based products. During this decade the price of raw sugar fluctuated both in the U.S and in the Caribbean since both regions were enduring the tail end of the slave abolition movement (Beckles and Shepherd 460). Thus, the company profited enormously from the decline in plantation sugar. 
Notably, sixty years later, during the period of the Vietnam war, Monsanto had become strongly affiliated with the U.S government. The peoples of Vietnam were fighting tooth and nail to fend off the U.S invasion of their homeland. American historians would never concede to the fact that during this time their troops were becoming increasingly demoralized due to the tenacious resistance mounted by the Vietnamese National Liberation Front (NLF). Indeed, in 1961 Monsanto was commissioned by the U.S military to produce a specific herbicide called 'Roundup' to counter this tenacity.

Along with other countless forms of genocidal, destructive tactics, the U.S decided to attack the NLF's food supply by spraying Roundup relentlessly over thousands of acres of Vietnamese villages, crops and jungle. This pesticide was branded 'Agent Orange' by U.S troops during the commencement of operation 'Ranch Hand'. The results were disturbing; hundreds of thousands of innocent Vietnamese peoples died due to severe poisoning of their food and even more horrifying were the multitudes of children born with birth defects $^{1}$. Rough estimates figure around over five hundred thousand children being born with major defects - all as a direct result of contact with Roundup while in the womb (Ruppert, 2011). Though the ramifications of Roundup still persist in present day Vietnam, Monsanto has never offered an explanation or an apology for their actions. On the contrary, the company's website offers a wellphrased organizational statement emphasizing the integrity, transparency and respect it has for the community (Monsanto Corp, 2006).

To date, the company is now ranked as a Fortune 500 company and employs 21,035 employees worldwide, with over 404 facilities in 66 countries (Monsanto Corp, 2006). With a multibillion dollar profit margin the company continues to genetically modify the genes of several plant and animal species. For the purposes of this essay, the focus will be on genetically modified crops (GM crops) as

\footnotetext{
1 Images $1 \& 2$ provided at the end of this section
} 
these crops are capable of resisting Roundup pesticides and give much larger yields than average.

Such hefty financial growth did not come without severe consequences. Numerous lawsuits continue to be filed, most focusing on transgenic contamination (which will be specifically discussed later on in this essay) and local farmers shared experience of their crops becoming cross-pollinated with Monsanto's GM crops. Other lawsuits tackle the bullying tactics Monsanto implements to force local farmers, both within North America and around the world to use their GM seeds.

In 2010, computer software giant, Bill Gates, made an unprecedented move by purchasing 500,000 shares of Monsanto stock through the Bill and Melinda Gates Foundation. Purchasing such a large percentage of the company brought further notoriety to the Gates Foundation. What is significant about this purchase was the unification of two ideologies which must be discussed.

The Bill and Melinda Gates Foundation is the largest private charity in the world. The foundation has billions of dollars at its disposal, which far exceeds the GDP of some small countries. Bill Gates, like his father, has been a strong believer and propagator of eugenics. $^{2}$ On the basis of this ideology, Gates approach to philanthropic work is extremely paternalistic; he largely views the world's population is in need of guidance and that citizens of the Global South are incapable of feeding themselves. Following this line of reasoning the responsibility of ensuring that there is enough food to feed the growing population falls upon the shoulders of Western powers who portray themselves as the benevolent, gracious nations. (Gates, 2012). Needless to say, Gates' ideology could be categorized as nothing less than a preposterous idiosyncrasy and nothing more than a hypocritical facade (Zizek 2011, 240). Regardless, Gates' eugenics ideology coupled with Monsanto's genetic manipulation of

\footnotetext{
${ }^{2}$ Eugenics is the selective breeding of certain traits in human populations as a method of proposed human improvement; some view it as the self-directed human evolution (Merriam-Webster 248)
} 
plants reveals a very important aspect of humanitarian aid work. It reveals that behind the charitable façade, there are many extremely problematic programs and strategies at work intended to maintain dependency so as to facilitate the continued exploitation of the global South.

It is commonly known that the Gates foundation does the bulk of its charity work within Africa and India as evidenced by constant bombardment of news relaying the foundations' hefty donations to people in lesser-developed countries (LDCs). These donations come in the form of dry and canned goods, water filtration facilities and more notably seeds (Gates, 2012). What the foundation fails to mention is where these food are sourced from and more importantly, the type of seeds given out by the Gates Foundation. Needless to say, Monsanto's GM seeds are freely distributed to peoples in the global south which in turn contributes to s threatening the remnants of independent agrarian societies. In short, the Bill and Melinda Gates Foundation, the world's largest private charity, single handedly distributes Monsanto GM seeds in the form of aid to foreign countries. This type of aid not only destroys the recipient country's agrarian economy, it deepens the country's reliance on food supply from the North, particularly from the U.S.

In addition to creating this dependency which has ultimately contributed to stunting the development of the global south, recent evidence has surfaced exposing Monsanto Corp as the new owner of the renowned mercenary group Blackwater now called Xe Solutions (Ribeiro,). The confluence of the Bill Gates foundation, Monsanto Corp and Xe Solutions illustrates an imperialist murderous mode of reasoning which concludes that the only way to save peoples of the south is to force them into total compliance ( Itwaru, 2011). With the Gates Foundation as the face, Monsanto Corp as the brain developing the seeds of destruction, and Xe Solutions providing the muscle and intelligence, this unholy trinity is a perfect manifestation of a new type of imperialism - corporate imperialism. To make matters worse, Monsanto Corp (Gates Foundation \& Xe Solutions included) is now close allies with The United States Agency for International Development (USAID). USAID is by and large a direct 
extension of U.S imperialism. As a result, this link between Monsanto Corp and USAID p means that countries who accept aid from the U.S. are also directly allowing Monsanto Corp access to their agricultural sector.

With such imperialist systemic practices at play, developing countries in the global south stand little to no chance at withstanding such an onslaught. However, there are some countries which have been successful in resisting and repelling Monsanto Corp altogether: Venezuela, Cuba, Haiti and Zimbabwe to name a few. The case of Haiti will be discussed later in detail. In the case of Zimbabwe, despite being a victim of 'Aid-bombs' (I use this phrase to emphasize the type of aid forcefully placed upon the peoples of Zimbabwe) and ladened with unnecessary sanctions, Zimbabwe has managed to survive without the help of the U.S. This does not mean that the U.S has actively stopped attempting to undermine Zimbabwe's agriculture sector by dropping large quantities of Monsanto GM corn in key areas of the country. Rather, that the people of Zimbabwe recognize these tactics of neo-imperialism and continue to destroy whatever vestiges remain of 'Aid-bombs' found within their country.

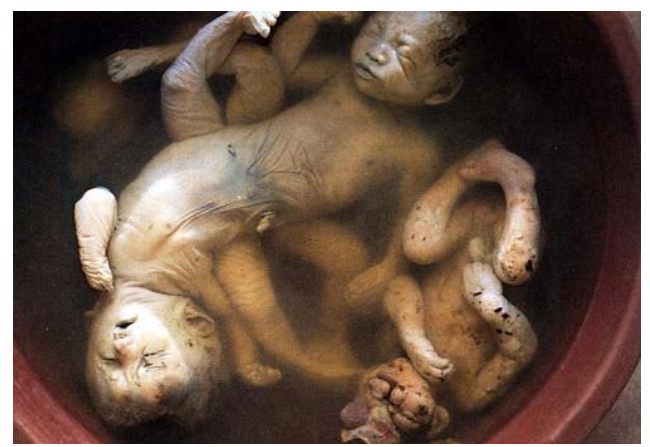

Image 1: Picture of deformed Vietnamese children due to their mothers being exposed to Monsanto's, 'Roundup' pesticide (Google Image). 


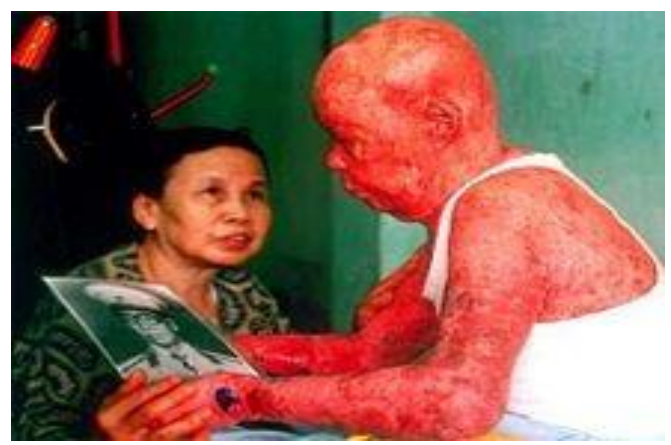

Image 2: A Vietnamese man who was doused directly with 'Agent Orange' also known as 'Roundup' (Google Image).

\section{Monsanto's Business Practices}

"...to achieve world domination, they no longer rely on bayonet-wielding soldiers. All they need is to control is food production..." Frederick Engdahal (Engdahl 2007, 74)

What gives Monsanto Corp the right to patent plant species from around the globe? By patent I mean the exclusive right to own and market specific plant genes. Moreover, when was this practice instigated and in what ways have governing authorities been kept neutral? In order to address these critical questions, a concise outline of the emergence of biotechnology and patenting practices must be given.

Near the end of the 1980's, the Dag Hammarskjold Foundation held a biotechnology meeting entitled, "Laws of Life". This meeting addressed emerging issues of genetic engineering and patenting, making it abundantly clear that giant companies such as Monsanto were rebranding themselves as companies of the "life sciences", whose goal was to control the world's agriculture through patents, genetic engineering, and mergers between companies. Further, changes included aggressively collecting plant seeds from around the globe and manipulating their properties in order to claim 'ownership' of these plant species. This process of comodification results in farmers not being allowed to keep Monsanto's GM seeds 
for replanting which results in farmers continually having to repurchase seed to sow. This means that farmers are consistently dependent on Monsanto for seeds and fertilizer with little opportunity to seek a transactional relationship elsewhere (Shiva, Monocultures of the Mind: Perspectives on Biodiversity and Biotechnology 1993, 25-29).

Every developing country (with the exception of Cuban and Venezuela) is forced to adhere to the WTO's rules and regulations in order participate in the global trading arena.. Part of this trade agreement requires that governments enforce of seed patent laws. This means that smaller countries are bullied into accepting patenting laws in order to generate economies of scale. In short, the entire framework of the World Trade Organization is designed to allow large MNCs such as Monsanto to penetrate foreign agromarkets, rendering them totally dependent on the North for food supply. Indeed, this predatory practice is not only backed by the WTO, but also by the U.S constitution, (which renders a corporation as a singular entity). This relationship has ensured that these corporations are protected and not liable for persecution in any court, whether foreign or domestic.

To further elaborate this point, analysis of Monsanto's dealings in India can be utilized to illustrate some of the specific tactics that Monsanto uses in order to gain control over food production. India's agricultural sector has suffered the most prior to their resistance against Monsanto. Due its wide array of soils, climates and large variety of plants, India is globally known for its large variety of staple crops. The peoples of the Himalayan Mountains eat several types of cereal grains, whereas the inhabitants in the western region use millet and those in Eastern India consume primarily rice and fish. This illustrates that each region has a specific set of dietary habits, unique to each sub-culture (Shiva 2000, 21)). Monsanto Corp realized the opportunity of patenting the majority of these plants as a means by which to establish any tangible control over the world's food market. 
Through direct and indirect links (NGOs, primarily the Bill \& Melinda Gates foundation and USAID), Monsanto began selling the idea of 'higher production yields' to the Indian government. In an attempt to compete on the global arena, the Indian government quickly capitulated and offered large tax breaks to Monsanto to conduct research and development within their country (Somerville and Santoni 1993, 347). From a political viewpoint, the Indian government could then claim that their country was friendly to foreign investment and charitable development, while Monsanto could demonstrate their prerogative to help impoverished peoples of the global south (Shiva et al 2003, 47).

In reality, what such development meant was the agricultural enslavement of local Indian farmers. In this context the term farmers, encompass the vast majority of Indian men and women who were coerced into abandoning their intergenerational crops for Monsanto GM seeds. Local farmers were promised vast returns for planting GM seeds, unbeknownst to them that these seeds contained 'terminator technology' which systematically cross pollinated with nearby crops and genetically altering them during the pollination process. In short, once farmers began planting GM seeds, whatever alternative crops existed before were destroyed once they pollinated with Monsanto seeds. This process is called 'transgenic contamination'.

This meant that farmers were now forced to plant only Monsanto seeds, since their alternating crops were mutating and unable to grow properly. To make matters worse, from the profits earned from their harvest, farmers were forced to continually repurchase fresh seeds to plant, instead of their intergenerational practices of saving their best seeds for the next year. What this translated to was further impoverishment of the peoples of India. Farmers mostly males committed suicide since they were unable to bear the strain of single crop-profit dependency. Women were now left to fend for themselves and their children; those who owned land were forced to sell to larger farmers since they were unable to till the soil. Some women went into prostitution, their children were either forced to join them or roam the streets in search of work. These are 
only but a few examples of the irresponsible practices by Monsanto Corp, which single-handedly disrupted a thousand year intergenerational practice of saving seeds, and also by transgenic contamination of native plant species.

Vandana Shiva, a world-renowned activist, propagates the right of freedom of seed for all which articulates that no company should be allowed the right to patent any plant. Moreover, her work with the local farmers within India garnered her national respect and admiration (Shiva, Manifesto on the future of seeds). Therefore, Shiva was able to mount the largest resistance within India against Monsanto Corp. Due to large civil outcry; the Indian government eventually capitulated and slapped Monsanto with a ban on their patenting practices. However, some reports still show that Monsanto still secretly collects plant samples from the region (Shiva, Stolen Harvest: The Hijacking of the Global food supply 75).

Not only is India severely affected; Mexico also experienced transgenic contamination, specifically with their corn species. Mexico is the global motherland of corn species. Their farmers rear the purest strains of corn, which up until recently, studies have shown that Monsanto GM seeds from the U.S have already begun cross pollinating with several Mexican strains. To date, a growing number of Mexican farmers and agricultural authorities are increasingly worried. Studies show within ten to fifteen years the majority, if not all of Mexico's indigenous intergenerational strains will be tainted by Monsanto terminator GM seeds (Image \& Compagnie, Productions).

The majority of the world's specimens of rice, cotton and legumes all originate from India. This is important to note since seeds for rice, eggplants, okra, bora and squash among others were brought across the Atlantic by indentured laborers to my specific case study of Guyana. Thus in a way, India was the source, the motherland, for a majority of crops within the Caribbean.

Why do Latin \& South America and the Caribbean seem to be the next major target market for Monsanto? More specifically, 
how does the Caribbean fit into the company's agro-empire expansion plan? In order to address these questions, one must consider the history of Caribbean mono-crop dependency, moreover, how the state of food security within the Caribbean is currently at its weakest.

\section{The State of Food Security in the Caribbean}

“...I am asked 'where is imperialism', just look into your plates: you see imported corn, rice or millet. This is imperialism, let's not look any further..."- Thomas Sankara (Sankara 62)

The Caribbean has a long history of mono-crop dependency, where most countries within the region earned the majority of their GDP through the growth of a specific crop. During colonialism the imperial powers constructed the Caribbean to be the sugar bowl, tobacco pouch, coffee shop and rum supplier of the world. The region was designed in this way to primarily produce sugar, tobacco, coffee and a variety of by-products associated with these three staple crops (Weis 185).

During the independence era, Caribbean economies were faced with the looming task of generating foreign exchange since their markets were now forced to compete on the global arena. In order to rectify the problem, St Lucian economist Arthur Lewis came up with the idea of 'Industrialization by Invitation'. The crux of his argument implied that most states within the region were dangerously reliant on agricultural production; it was urgent that states began to diversify their production. This meant that a massive shift away from agriculture production was in order.

Lewis theorized that the only way to diversify production was through an immediate injection of foreign cash. He propagated the need for Caribbean states to openly invite foreign investors into their countries. In short, the imperial powers never really left the Caribbean - the system only recalibrated itself and created a new framework in which to operate. Whether Lewis was naive or coerced by foreign powers to create such dependency theories remains a 
mystery. The important fact to consider, however, was that most heads of state within the Caribbean with the exception of: Cheddi Jagan, Michael Manley, Fidel Castro and Maurice Bishop, willingly complied. This was due to their trained dependence on foreign assistance. By trained, I mean the ongoing mythology of the West as civilized, contrasted with the Caribbean in need of their 'help'. This mindset allowed foreign powers, particularly financial institutions, to implement crippling policies which further underdeveloped the region.

Violence is articulated in a number of different ways and in the context of the Caribbean we can see how potently systemic it is. The foreign powers knew that in post-independent Caribbean, any type of continual military invasion would have incurred severe resistance within the region. It was important for this reason to keep the region under control subtly through financial means. When the price of oil skyrocketed in the 1960's, most Caribbean countries (with the exception of Cuba), were once again in need of foreign exchange and immediate loans. The foreign powers created the IMF and the World Bank to offer larger than needed loans to countries at high interest rates, and to make matters worse, these financial agencies ensured that they implemented structural adjustment programs within the borrowing countries to facilitate a faster rate of repayment. Needless to say, these adjustment programs were designed to overburden the fragile Caribbean economies, consequently plunging them into a spiral of foreign aid dependency, much like Monsanto's practices with Indian small farmers.

Therefore, the Caribbean community became displaced and subdued amidst the steadily encroaching takeovers by multi-national corporations, the continual economic incapacitation by the IMF structural adjustment program and the restrictive practices of the WTO. Through this three-prong approach (policies of MNCs, the IMF and WTO) there is a steady decline of agrarian practices within the Caribbean. Such a decline poses a severe threat to these small nations already facing significant levels of debt. The Caribbean, with the notable exception of Cuba, has succumbed to food dependency 
on the North, thus rendering them into nothing more than 'Bread Basket Dependent States' (Weis).

Monsanto Corp made its initial entrance into the Caribbean not through the standard rearing or sale of crops, but primarily from the influx of fast food restaurants. I argue that the influence of U.S media coupled with the flooding of U.S subsidized goods onto Caribbean shelves, stimulated the population's taste for foreign foods verses their own domestic produce. In short, as the daily diet changed to include these foreign products, citizens within the Caribbean began to consume mass amounts of food from U.S based fast food restaurants. This mass consumption resulted in permanent dietary dependency and more importantly, stronger reliance on Monsanto grown ingredients, which interconnected with the rise of U.S fast food restaurants. Thus, restaurants such as McDonalds, Kentucky Fried Chicken and Wendy's produce foods with Monsanto GM ingredients.

Breadbasket dependency (BBD) was a primary concern for four pivotal leaders in the Caribbean. In Guyana, Cheddi Jagan made it a part of his 1992 campaign promise to ensure that fast food companies were using local ingredients; that protective tariffs be placed on imports to ensure the future viability of local produce. Moreover, Jagan began reintroducing policies in local government that would gradually reduce the influence of MNC and other foreign institutions within Guyana (Jagan, The West on Trial, My Fight for Guyana's Freedom 145).

Michael Manley in Jamaica and Maurice Bishop in Grenada also began designing grow local-eat local programs within their respective countries. The USA ensured that they were unsuccessful; they used the CIA to undermine the Manley government and invaded Grenada under the pretext of stopping communism (Jagan, The USA in South America and Other Essays 52). To date, the only Caribbean country that managed to break free from food dependency and reach a high level of self-sufficiency is Cuba. Under the leadership of Fidel Castro, the peoples of Cuba worked hard to diversify their economy without external help, though this did not without obstacles. Cuba 
today nonetheless, in my perception, is the strongest agro economy in the Caribbean and is impenetrable, and dare I claim impervious to MNCs such as Monsanto.

It is clear now that the phenomenon of the breadbasket dependency provided a clear inroad for MNCs into the Caribbean market. But what about other countries in South America - why is Monsanto so keen on establishing large bases within that region? To answer these questions, I will briefly highlight Monsanto's current 'development' projects within the Caribbean and in South America.

Monsanto's Involvement within the Caribbean and South America

“...the savage exploitation of rainforests continues in South America. Trees are felled like dumb creatures. River catchments are impoverished. The muse of nature within the consciousness of peoples is threatened..."- Wilson Harris (Harris 44)

In reality, Monsanto has been intricately intertwined in the agro-affairs of the Caribbean and in South America since the 1980s. As mentioned previously, their involvement within the region came hand in hand with the U.S of aid relief, particularly through NGOs such as USAID, CIDA, SIMAP, Food for the Poor, Bill and the Melinda Gate Foundation among others. For the purposes of this essay, I will address two pivotal countries in which Monsanto has its strongest involvement. Finally I will discuss the only recent resistance to Monsanto Corp within the region.

In 1983, the company established a relationship with Puerto Rico through USAID and the US government's 'Operation Bootstrap'. Operation Bootstrap was a new U.S foreign policy that facilitated the insertion of large MNCs into the Puerto Rican economy. According to the U.S government, this was the development of democracy at its finest (Klein 48). In reality what transpired was the obliteration of Puerto Rico's agro-system, which forced the population to be dependent on foreign foods. 
In 2007, Monsanto returned to Puerto Rico to plant their GM corn on a large scale. Their primary purpose was to test their new MSP hybrid seeds (crosses of corn females and males. Once planted, these seeds were sprayed constantly with Rogueo and Desespigue pesticides, all designed by Monsanto). The corn once ripened, are mechanically harvested and stored in two major plants: Isabela and Juana Diaz. These two factories own and control a combined size of 2,325 acres (the approximate size of Puerto Rico is 23,733 acres). In this way Monsanto Corp has direct control of roughly $12 \%$ of the country's landmass, in addition to employing close to 400 people on the island. The seeds produced from these two factories are called "grandparents" and are packaged and sold to farmers worldwide. Puerto Rico, in this way, serves as a global cornseed processing plant for the company (Martinez).

Monsanto arrived in Brazil in 1963. Since then, it has firmly established a solid foothold over the Brazilian agro-industry. The company produces herbicides and seeds for corn, soybeans, cotton and vegetables. More importantly, in 2008, Monsanto acquired Aly Participacoes Ltd and CanaVialis Ltd, two companies focused on sugarcane breeding technology and are both based in Brazil (Monsanto Corp). With this acquisition came the control of all soy, sugar cane and cotton production within Brazil.

What makes Brazil so important to this discussion is primarily because of the immense rainforest located within the country. Brazil is the fifth largest country in the world and its Amazon rainforest is affectionately called the 'lungs of the earth'. Moreover in recent times, Brazil's economy has been growing at close to $8 \%$ a year, making it an attractive investment for foreign companies. With such a strong, emerging economy, Brazil vies to be recognized and classified as a 'first world country', even at the expense of the further impoverishment of its citizens.

Monsanto, recognizing the economic potential of Brazil as the breadbasket of South America, ensured that they controlled most major crops within the country. Now more than ever, Monsanto is growing larger quantities of GM soybeans, cotton, sugar cane and 
rice. But in order for Monsanto to acquire more fertile land, the company is encouraging the destruction of the Amazon by local landowners in return for huge profits. It is not surprising that landowners are somehow able to acquire Monsanto manufactured Agent Orange chemicals that were used in Vietnam.

According to recent reports dated July 2011, large landowners in the Amazonian region are actively spraying thousands of acres of pristine jungle with Agent Orange. One landowner was discovered to harbor over four tons of the pesticide. Local activists were able to identify and photograph large tracts of now dead forests ${ }^{3}$. Some reports estimate that approximately 10 acres of Amazonian rainforest is cleared daily by local landowners keen on planting Monsanto GM seeds (Messenger).

One could also speculate that due to Monsanto's close ties with U.S foreign policy, the company is allowed to expand in order to apply more pressure on the peoples of Venezuela and Chile against their governments. As discussed previously, Monsanto's seeds contain 'Terminator Technology' which once pollinated with native strains of core plants begins the transgenic contamination process. Thus, with GM seeds being sowed abundantly right outside of their borders, the revolutionary movements within Venezuela and Chile could be undermined due to food contamination.

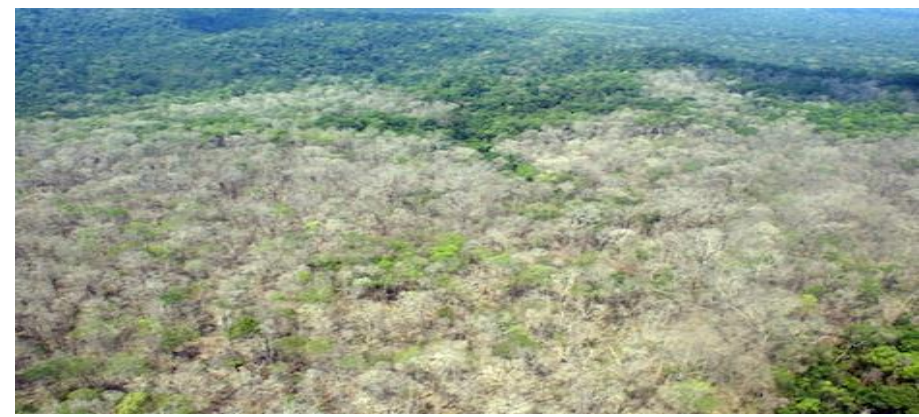

Image 3: Ariel view of Amazonian forests sprayed with Agent Orange. Note the large tracts of lifeless trees.(Picture by: Stephen Messenger) (Messenger)

3 See Image 3. 
The Case of Guyana

What is rain for, if not rice

for an empty pot; and pot for

in a hungry village? The son

succeeds his father in a line

to count as he did, waiting,

adding the latest to the first

of his losses; his harvests

of quick wind padi...

- 'Rice' by: Martin Carter (Carter 89)

Indentured labourers from India made painstaking sacrifices to bring seeds from their motherland to the Caribbean. This action, in a way, clearly showed a deep connection between agricultural practices and cultural attitudes. In short, peoples of the South knew the importance of food independence. These connections still remain embedded in Guyanese society (Jagan, The West on Trial, My Fight for Guyana's Freedom 32). Like Mexico with corn, Guyana firmly established itself as a pseudo-home for rice and its cultivation within the Caribbean.

In Guyana, rice and sugar cane are the two largest crops produced within the country. Under the leadership of Cheddi Jagan during the 1960s, Guyana was affectionately known as the 'breadbasket of the Caribbean'. This ideal was further ingrained when Dr. Jagan began introducing subsidies and stimulus packages designed to encourage local farmers to grow more food (Jagan, Forbidden Freedom: The Story of British Guyana 87). One sector that grew rapidly under Jagan's policies was the rice industry.

Thus, there was growing pressure on the plantocracy to allow small farmers to save more of their rice-paddy for the following year and allowances for more agricultural land. Most agricultural reform policies came to a crashing halt when Dr. Jagan was forcefully removed from office during the British invasion. The actions of the British were costly for the peoples of Guyana. The people witnessed the betrayal and removal of Guyana's only honest 
politician, the only politician who genuinely wanted the unification of his citizens in a socialist, political and economic culture.

Things changed dramatically due to the IMF's structural adjustment programs of the 1990s. President Hoyte succumbed to foreign pressure and allowed tariffs to be removed on all foods imported into the country. This meant that local farmers were now forced to compete with heavily subsidized U.S farmers. Farmers in the U.S are subsidized by up to $80 \%$ by the U.S government, and they are strongly encouraged to overproduce, the excess of course is dumped into foreign food markets, such as in the case of Guyana. In short, the produce of Guyanese farmers was more expensive than foods imported from the U.S. To further the damage, the WTO began implementing stricter trade policies, which limited the quantity of rice being exported. These two acts of systemic violence against the peoples of Guyana crippled the agriculture sector, rice production in particular.

To date, the rice industry has shrunk substantially. Larger farmers were forced to amalgamate, and consequently small farmers were forced into selling their lands. Those who refused to sell at first are now forced to wait in long lines for days at a time to sell their rice-paddy to on a few mills left in the country at below market value. Rice millers have thoroughly accepted standardized packaging practices, selling only rice grains of a specific size, discarding or selling everything else at well below their market value. This type of standardization forced farmers to discard their ancient seeds and seek modified seeds, which had larger yields and were up to WTO and Milling specifications.

The question then arises, when exactly did Monsanto Corp enter into the Guyanese rice market? Based on my research, the company made its most notable incursion in 2009 when Guyana's National Agricultural Research Institute signed a major deal with U.S based Stine Seed Company (Stabroek News). The agreement meant that Guyana would provide space for Stine Seed Company to continue developing 'hybrid seeds' in exchange for local researchers to learn more about GM technology. This company also assisted with 
research and development for the 'Rustic Backcross-Breeding Program', which was implemented by the Guyana Rice Board. More importantly, what I discovered after scrutinizing the Stine Seed Company was that they are a subsidiary of Monsanto Corp, and are listed on their website as an active partner (Monsanto Corp). This connection in itself validates my argument concerning Monsanto's involvement indirectly in Guyana.

To make matters worse, due to the enforced standardization of rice grains on local farmers, the Guyana Rice Board implemented a series of 'promotional campaigns'. From 2000 to the present, the Guyana Rice Board has actively propagated the G98 Rice Grain series. The chart below shows the specific grain and the description attributed to it by the GRB.

\begin{tabular}{|l|l|l|}
\hline $\begin{array}{l}\text { Year } \\
\text { Released }\end{array}$ & $\begin{array}{l}\text { Series of Rice } \\
\text { Seed }\end{array}$ & Description by the GRB \\
\hline 2000 & G98-22-4 & $\begin{array}{l}\text { An extra long grain, high quality, locally } \\
\text { developed from the Rustic backcross- } \\
\text { breeding program. }\end{array}$ \\
\hline 2000 & G98-24-1 & Same as above \\
\hline 2000 & G98-30-3 & Same as above \\
\hline 2010 & G98-135 & $\begin{array}{l}\text { *An extra long grain, high quality, locally } \\
\text { developed from the Rustic backcross } \\
\text { breeding program which has not been } \\
\text { officially released as yet but is occupying a } \\
\text { significant portion of the commercial acreage }\end{array}$ \\
\hline
\end{tabular}

(Guyana Rice Developent Board)

What is most notable in this chart is the constant resort by the GRB towards the G98 series. After extensive research and according to scientific patenting reports in 1998, Monsanto Corp modified and patented the G98 rice grain and all other G98 series following (Prior IP). On record, the Government of Guyana has not conceded to the use of Monsanto GM seeds. However off record, I was able to secure information that government officials were strictly 
warned to remain mute on the issue since, "...it made the ministry of agriculture look bad..." (De Mendonca).

Another disturbing connection involves Monsanto Corp, Oxford University and some of the indigenous peoples of Guyana. In 2001, Oxford University began conducting an ethnobotany program among Macushi women within the interior of Guyana. True to its description as a way of encouraging the development of women, Oxford researchers encouraged indigenous women to bring plants that contained medicinal or healing properties. The Macushi women, however, were paid mere pittances for their work and were told that the plants would be used for research to develop pharmaceuticals (Dilly 61).

The connection here is based on recent cash incentives Oxford University has been getting from Monsanto Corp to conduct research and development throughout the global south. Recently, Oxford University Press allowed for the publishing of a book that praised Monsanto for taking a realistic and bold step in feeding the world's poor and attempting to alleviate hunger (Lappe). I would not be surprised if Oxford's ethnobotany program in Guyana is nothing more than a glorified scheme to exploit indigenous peoples of their knowledge of medicinal plants to benefit Monsanto Corp, who would patent them immediately.

Such gross exploitation of a MNC within a country like Guyana can still be interpreted as abstract and without base. This is why I will attempt to address these same exploitative tactics within the parameters of my childhood village of Hauraruni (pronounced, Har-ra-roo-ni). I will give a quick outline of Monsanto's influence in my village and how with the help of USAID has begun destroying childhood home.

\section{USAID \& Hauraruni Friendly Farmers Society}

“...de guvament nah do nuttin fuh we, all dem ah tink bout now is how fuh full dem pocket. Suh wah yuh want we do, nah guh back to dem white men fuh look a wuk...”-Delroy Wong (Wong) 
The name Hauraruni is speculated to derive from an indigenous word that meant 'land of plenty'. My village adopted its name from the beautiful Hauraruni creek which gracefully shaped its way around 460 acres of fertile land and finally empties into the mighty Demerara river. My village is approximately forty miles away from the capital city of Georgetown and is about three miles away from the main highway.

With such a rich arable land, most people within my community were involved in agriculture. I still have fond memories of fields of golden pineapples, pear and cashews trees, the sweet smell of the silverballi tree in its annual bloom, the acres of watermelons and the childhood joy of communal living. Through combined communal living my village was able to sustain itself. This all came to a grinding halt in the 1990 s due to the IMF structural adjustment program.

Within a year farmers in my community were forced to sell their produce significantly lower than the market value in order to save their client base. As the years went on one by one, or sometimes by groups, farmers and their families - people whom I considered my family were forced to do two things: griped by hunger and humiliated by their empty pockets, most villagers left farming completely and became loggers or sold their lands and moved to the city in search of work. Most people I knew sold their land never to return were or even visit simply because they could not afford to, or felt that they had to 'make it' in order to be perceived as a success. By 2009, most the people from my village were desperate to generate revenue by whatever means necessary.

In December 2010, USAID initiated its 'friendly farmers' program in Guyana; their stated goal was to teach farmers new and innovative ways to grow crops. With few other options available to them, leaders from my community felt that they should approach USAID for help, since close to 20 farmers and their families were out of work and wanted to return to the soil. Due to the NGO's policy, the villagers were required to create a name for their group, more importantly they needed to provide a substantial size of land if 
USAID were to be interested. Within six months, the group returned to the NGO with a presentation of 25 acres of land - what the villagers did was to combine their land holdings in order to 'impress' the USAID representative (Fredericks).

Once the papers were signed, USAID introduced the group to their technical supervisor, Mr. Nir Dahan. Upon researching his background I discovered some very disturbing news, Mr. Dahan worked directly for CARANA Corp, a company with close connections to Monsanto Corp. I found out that CARANA Corp created major inroads for Monsanto in parts of Africa (Quin). This meant that both corporations had a longstanding relationship with one another. According to CARANA, their company with the generous support of USAID, was modernizing the agro-sector in Guyana and valued the project in Hauraruni at approximately USD\$250,000. I was only able to discover this due to CARANA's mandatory report to the United States Agency for International Development, which must be made available to the public. The question then arises, precisely what did CARANA Corp through USAID do with USD $\$ 250,000$ dollars? The answer is horrifying due to the evidence I have accumulated.

The first edict given to the group was a total deforesting of the area; this meant that over 25 acres of jungle was cleared4. With the help of heavy machinery and under the guidance of USAID officials, the farmers razed much of their village land, in the hopes that better days were ahead for them. After clearing the forest, all that was left was raw exposed dried sand. According to USAID officials, this was perfect soil for planting. Seedlings were grown in a makeshift nursery and according to villagers required large amounts of pesticide. Officials demanded that young papaya plants were planted strictly 4 feet apart from each other, even though villagers felt this was wrong5. As was said by one villager, “...meh neva see wan papaya tree grow suh fass and suh close together, dis ting cyan be right..." (Wong).

4 See Image 4

5 See Image 5 
In addition to the deforestation and growing practices, what should be noted is the use of harsh pesticides. According to workers there, they are forced to spray the plants two times a day with a chemical called Duoguard 11 and RT 3. Also, I have received first hand reports of fertilizer 20-20-20 being pumped continuously into the sand. The only type of plant that requires such large amounts of water, pesticide and fertilizer are GM modified seedlings. Moreover based on research RT 3 is a patented Monsanto product. During my research I was able to uncover classified evidence that showed RT 3 causing intergenerational cancerous cells on test animals, much less humans who work and consume those plants (Monsanto Corp). Even 20-20-20 fertilizers are distributed by Caribbean Chemical, another representative of Monsanto Corp (Caribbean Chemicals).

To date, USAID has pushed most of the villagers away, claiming that they are inefficient and not needed at the farm. This means that the villagers who contributed their own land are now being disposed and displaced. More importantly, the community structure has been totally discombobulated; young people who were motivated at the idea of earning income on a collective basis are seeing the destruction of their home and are reacting violently.

The sales of the produce do not benefit the villagers but go to servicing the large debt placed on the group. From personally trespassing in the area (based on my studies and level of education, instructions were left by officials not to allow me onto the farm) I know for a fact that USD\$250,000 was not spent on developing the area. From my estimations I would say approximately USD $\$ 60,000$ was spent, and those are generous calculations. One can only wonder where or to whom the remainder of the funds go, these questions swirl in my mind more and more whenever a USAID or CARNA official drives through my village in an expensive Range Rover. 
CARIBBEAN QUILT | 2013

Image 4: Partial view of cleared Forest. ${ }^{*}$ Notice the total destruction of the Soil. (Image from Delroy Wong)

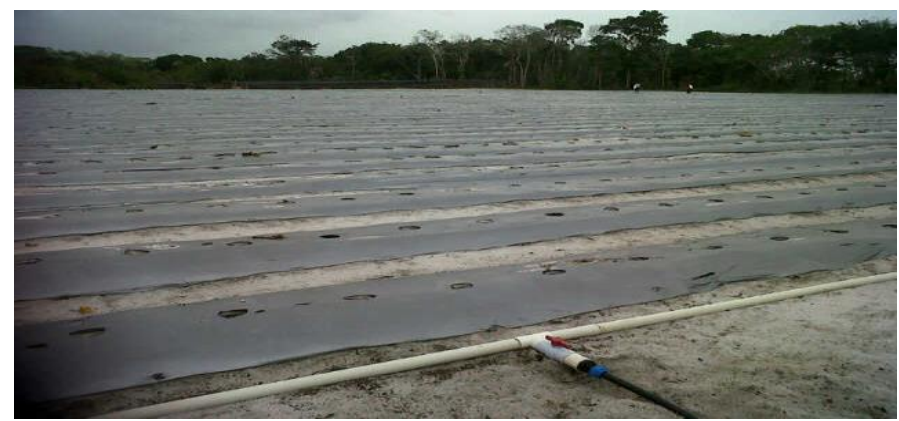

Image 5: GM Papaya plants being reared on 20-20-2O fertilizer and $\mathrm{RT} 3$ (Image by Delroy Wong) - Below

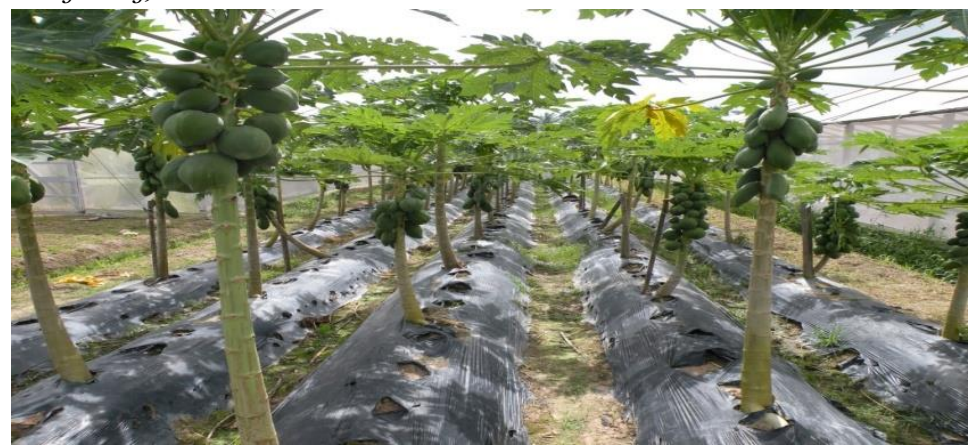

Image 6: Inside view of GM seedling nursery (Image by Delroy Wong)- Below

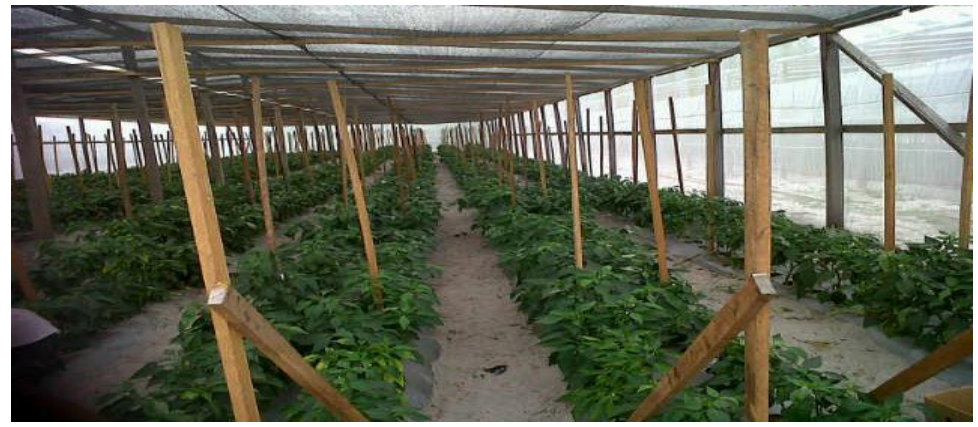


Image 7: Pump used to irrigate plants with Monsanto pesticides (Image by Delroy Wong)

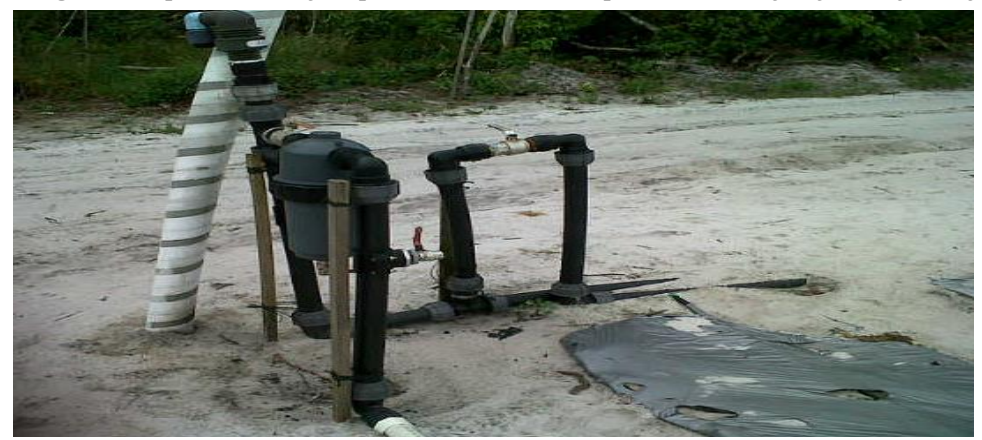

Conclusion

“...My philosophy: Very simple- the world is big and can provide amply for allthere need not be poverty and suffering. Man is capable, given the opportunity of fantastic cultural and intellectual attainment. But first there must be an end to the system of capitalism- the system which because it is based on individual greed breeds insecurity, poverty, ignorance and suffering..." - Cheddi Jagan 1964

To conclude this argument is extremely difficult, primarily because the discourse continues. Daily situations, such as Hauraruni, repeat themselves globally. Millions of peoples in the global south suffer at the hands of this new form of imperialism. The time has come for a significant shift away from such capitalist practices. The only way to do so is from the ground up, from the community level where small groups of people can be de-educated away from colonialist methodology and re-educated to the realities of the world around them.

It is important to note the threats posed to this research. I lost count the number of times I was told to cease asking questions relating to the farm in Hauraruni. Close friends of mine were threatened to be fired from work if they were caught taking any pictures on my behalf. To compound this situation, some of the youth of the village are unhappy with the circumstances their parents have placed them in. In addition, my contacts within the ministry of agriculture (Guyana) were threatened and were slapped with the 
directive that if they were to divulge any information, they would lose their contracts. Regardless of these threats, some government employees still pointed me in the right direction in terms of acquiring answers. The rice farmers are constantly threatened, not only by rice millers, but also by members of government, who explicitly make it clear to the famers that they would face severe consequences if any of them were to be found providing information. Irrespective of these threats, the majority of farmers I met were warm, courteous and willing to discuss the issues, off record.

Once small communities begin developing themselves without the help of foreign aid, and then their government will be increasingly held accountable. No more will local governments continue disrespecting famers by freely distributing GM modified seeds to the impoverished under the cloak of 'grow more food' campaigns (De Mendonca). No more will USAID officials get away with such blatant underdevelopment processes. No more will they feel comfortable living a lavish lifestyle while we work in subservience towards their interests and not ours.

The time has come for communities to develop their own homegrown methodology of food security. The structure needs to be reshaped to accommodate the voices of Guyana's indigenous population. Perhaps a good example of real agricultural development can be best attributed to President Hugo Chavez. President Chavez expelled Monsanto completely out of Venezuela and immediately implemented new policy, which barred the company from ever returning and also from patenting anything belonging to the peoples of Venezuela. The time has come for change, it must come from within and discourse must continue. 


\section{Works Cited}

Alleco, Ina and R Silverio. "Building Socialism through People's Economic Participation in Venezuela." 15 July 2011. Venezuela Analysis. 22 April 2012 <http://venezuelanalysis.com/analysis/6354>.

Ananda, Rady. "Lawsuit seeks to invalidate Monsanto's GMO Patents." 2 April 2012. Global Research. 22 April 2012

<http://www.globalresearch.ca>.

Balloil. "Guyana to Establish Centre for Biodiversity Study." 16 May 2012. Windies Forum. 22 April 2012

<http://www.windiesfans.com/forums/viewtopic.php?f=4\&t=322\#p2316>.

Beckles, Hilary and Verene Shepherd. Caribbean Slace Society and Economy. New York: The New Press, 1991.

CARANA Corporation. CARANA Contract Vehicles. 01 January 2012. 22 April 2012 <http://www.carana.com/contractvehicles>.

-. Modernizing agribusiness in Guyana. 01 January 2012. 22 April 2012 $<$ www.carana.com $>$.

Caribbean Chemicals. Our History: Caribbean Chemicals. 01 January 2009. 22 April 2012 <http://caribbeanchemicals.com/general/our_history.php>.

Carter, Martin. Poems by Martin Carter. Oxford: Macmillian Publishers Limited, 2006.

Chossudovsky, Michel. The Globalization of Poverty and the New World Order. Quebec: Global Research, 2003.

De Mendonca, Arnold. The use of GM Foods in Guyana Mark Chatarpal. Georgetown, 06122011.

Dilly, Barbara J. Gender, Culture, and Ecotourism: Development Policies and Practices in the Guyanese Rain Forest. Georgetown, 16 September 2003.

Engdahl, Frederick William. Seeds of Destruction: The Hidden Agenda of Genetic Manipulation. Torono: Global Research Publishers, 2007.

Fredericks, Vivian. Hauraruni Farm Co-op Mark Chatarpal. 23122011.

Gates, Bill. Living Proof Project. 01 January 2012. 22 April 2012 <http://www/gatesfoundation.org/livingproofproject/pages/usaid.aspx>. 
Guyana Rice Developent Board. Guyana Rice Development Board. 0101 2010. 22 April $2012<w w w . g r d b . g y>$.

Harris, Wilson. Selected Essays of Wilson Harris; The Unfinished Genesis of the Imagination, Expedition into cross-culturality; into the labyrinth of the family of mankind, creation and creature; into space, psyche and time. London: Routledge Publications, 1999.

Huff, Ethan. "Bill Gates, Monsanto, and eugenics: How on of the world's wealthiest men is actively promoting a corporate takeover of global agriculture." 29 Febuary 2012. Natural News. 22 April 2012 <http://www.naturalnews.com/035105_bill_gates_monsanto_eugenics.ht $\mathrm{ml}>$.

Itwaru, Arnold Harrichand. Body Rites, Beyond The Darkening. Toronto: TSAR Publications, 1991.

Jagan, Cheddi. Forbidden Freedom: The Story of British Guyana. London: Hansib Publishing Limited, 1989.

-. The USA in South America and Other Essays. London: Hansib Publications, 1998.

-. The West on Trial, My Fight for Guyana's Freedom. Glasgow: Hansib Publications, 1997.

Klein, Naomi. The Shock Doctine: the raise of disaster capitalism. Toronto: Random House of Canada Limited, 2007.

Lappe, Frances Moore. "Cheerleading for Monsanto? The Shocking Lack of Difference Between Oxford University Press and Fox News." 9 April 2012. Alter Net. 22 April 2012 <http://www.alternet.org/food/154923>.

Martinez, Elivan. "Monsanto's Caribbean Experiment." 21 November 2011. Organic Consumers Association. 22 April 2012

<httop://www.organicconsumers.org/articles/article_24406.cfm>.

Merriam-Webster. The Merriam-Webster Dictionary. Markham: Pocket Book Publishers, 1074.

Messenger, Stephen. "Vietnam Era Weapon Being used to Clear the Amazon." 5 July 2011. Tree Hugger News. 22 April 2012 <http://www.treehugger.com>.

Monsanto Corp. "Classified Material Safety Data Sheet." 30 January 2006. ChemCas. 22 April 2012 
<http://www.chemcas.com/msda_archive/part2/cas/gf_msds/monsanto_ com---rt_3_msds.asp >.

-. Monsanto Brazil. 01 Janurary 2012. 22 April 2012 <http://www.monsanto.com.br/institucional/monsanto-no-

brasil/historia.asp>.

-. Monsanto in Puerto Rico. 01 January 2012. 22 April 2012 $<$ http://www.monsanto.pr/nuestra_empresa/historia/monsanto_puertorico .asp>.

-. Our Goal: Monsanto Corp. 01 January 2012. 22 April 2012 $<$ www.monsanto.com>.

-. "Our products: Stone Seed Group." 01 January 2012. Monsanto Corp. 22 April $2012<w w w . m o n s a n t o . c o m /$ products/pages/stone-seed-group.aspx>. -. Speciality Crop Pipeline. 01 January 2012. 22 April 2012 $<$ htto://www.monsanto.com/products/pages/speciality-croppipeline.aspx>.

Panitch, Leo, Greg Albo and Vivek Chibber. The Crisis And The Left; Socialist Register 2012. Wales: The Merlin Press, 2011.

Prior IP. Patent Code for Monsanto Corp. 20 December 1998. 22 April 2012 $<$ www.prior-ip.com/patent/1728149>.

Quin, Leah. "New Director, more directions for Trade Hub." 1 November 2007. West Africa Trade Hub: making trade happen. 22 April 2012 $<$ http://www.watradehub.com/pt-pt/node/530>.

Ribeiro, Silvia. "Machines of War: Blackwater, Monsanto and Bill Gates." 30 January 2012. Infowars.com. 22 April 2012 $<$ http://www/infowars.com/machines-of-war-blackwater-monsanto-and-billgates-2>.

Rodney, Walter. How Europe Underdeveoped Africa. Washington : Howard University Press, 1982.

RT News. www.rt.com. 1404 2012. 22042012

<http://rt.com/usa/news/farmers-crop-monsanto-dow-pesticide-411/>.

-.www.rt.com. 1104 2012. 22042012

<http://rt.com/usa/news/monsanto-farmers-tobacco-use-809/>.

Ruppert, Madison. "The World's Largest Human Experiment Part 1: GMO's, Roundup and Monsanto Monstrocity." 11 July 2011. Activist Post. 22 April 2012<http://www.activistpost.com/2011/07/words-largest-humanexperiment-gmos.html>. 
Sankara, Thomas. We Are Heirs of The World's Revolutions; Thomas Sankara, Speeches from Burkina Faso revolution 1983-87. New York: Pathfinder Press, 2007.

Shiva, Vandana. Earth Democracy: Justice, Sustainability and Peace. London: Zed Books Ltd, 2005.

-. "Manifesto on the future of seeds." 01 January 2012. Vandana Shiva. 22 April 2012 <http://www.vandanashiva.com>.

-. Monocultures of the Mind: Perspectives on Biodiversity and Biotechnology. London: Zed Books Ltd, 1993.

-. Stolen Harvest: The Hijacking of the Global food supply. Cambridge: South End Press, 2000.

Shiva, Vandana, et al. Biodiversity: Social \& Ecological Perspectives. London: Zed Books Ltd, 2003.

Shrivastava, Dr. Arun. "Weaponization of the food system: Genitically manipulated maize threatens Nepal and the Himalayan." 24 April 2012. Global Research . 24 April 2012 <http://www.globalresearch.ca>.

Somerville, John and Ronald E Santoni. Social And Political Philosophy: Readings from Plato to Gandhi. New York: Anchor Books, 1993.

Stabroek News. "NARI signs seed research pact with US Companies." 30 July 2009. Stabroek News. 22 April 2012 <http://stabroeknews.com>.

The Murderous Mode of Reasoning. By Arnold Itwaru. Perf. Arnold Itwaru. New College , Toronto. 19112011.

The World according to Monsanto. Dir. Marie-Monique Robin. Image \& Compagnie, Productions. 2008.

Urfie, Jean-Yves, Mervyn Claxton and Zili Danto. "A New Earthquake Hits Haiti: Monsanto's deadly gift of 475 tons of genetically-modified seeds to Haitian Farmers." 13 May 2010. Norman Garvin. 22 April 2012 <http://www.normangirvan.info/wpcontent/uploads/2012/05/monsanto.htm>.

Weis, Tony. Labour, Capital and Society: Agrarian Decline and Breadbasket Dependence int he Caribbean: Confronting Illusions of Inevitability. London: University of Western Ontairo Press, 2003.

Wong, Delroy. Hauraruni Farm Co-op Mark Chatarpal. 28122011.

Ziegler, Jean and Siv O'neal. "Fuelling World Hunger: How the Global Biofuel Industry Is Creating Massice Destruction." 11122011. 
www.globalresearch.ca. 22042012

<http://globalresearch.ca/index.php?context=va\&aid=28434>.

Zizek, Slavoj. Living In The End Times. London: Verso Publication , 2011. 